\title{
PENGARUH INVESTASI ASING LANGSUNG DAN MODAL MANUSIA PADA PERTUMBUHAN EKONOMI INDONESIA
}

\author{
Endang Syahriani ${ }^{1 *}$ \\ 1, Dosen Magister Manajemen Fakultas Ekonomi Bisnis UNIKI \\ *email: esyahriani@yahoo.co.id
}

DOI:

https://doi.org/10.55178/idm.v1i2.198

ABSTRACT

\section{Article history}

Received:

September 14, 2020

Revised:

September 20, 2020

Accepted:

September 30, 2020

Page:

$76-80$

Keywords:

foreign direct investment, human capital and economic growth
This paper examines the role Foreign Direct Investment and Human Capital on Economic Growth in Indonesia. The data used in this research are time series data period from 1990 to 2012. Data obtained from the website of World Bank. The results showed that the Foreign Direct Investment and Human Capital affect economic growth in Indonesia. Of both independent variables, Human Capital variable compared to Foreign Direct Investment variable more affect economic growth.

\section{Pendahuluan (Introduction)}

Dalam rangka menilai kinerja perekonomian, salah satu indikator yang sering digunakan adalah pertumbuhan ekonomi, terutama pada saat menganalisis hasil-hasil pembangunan ekonomi yang dilaksanakan suatu negara atau daerah. Jika produksi barang dan jasa meningkat dibanding tahun sebelumnya, dikatakan ekonomi akan tumbuh. Oleh karena itu, pertumbuhan ekonomi menunjukkan bagaimana kegiatan ekonomi menghasilkan pendapatan tambahan atau kesejahteraan sosial dalam kurun waktu tertentu. Pertumbuhan ekonomi suatu negara atau wilayah akan menunjukkan bahwa ekonomi negara atau wilayah tersebut berkembang dengan baik.

Dalam rangka meningkatkan pertumbuhan ekonomi, perlu dilakukan investasi yang bertujuan untuk meningkatkan output barang dan jasa yang dihasilkan. Oleh karena itu, pemerintah tidak hanya harus menyediakan infrastruktur ekonomi bagi dunia usaha, tetapi juga berperan serta langsung dalam mendorong perkembangan dunia usaha melalui kebijakan yang dapat mendukung pengembangan investasi.

Menurut pendekatan neoklasik Solow (1956), pembentukan modal dan pertumbuhan penduduk merupakan faktor-faktor yang memiliki pengaruh signifikan terhadap pertumbuhan ekonomi suatu negara. Dalam hal pembentukan modal, peran penanaman modal dalam dan luar negeri melalui penanaman modal asing secara langsung ( FDI) adalah Pertumbuhan ekonomi telah memberikan kontribusi yang sangat besar.

Liu dan Su (2016) menggunakan metode Human Capital Augmented Solow Model mendapatkan hasil penelitian yang menunjukkan bahwa laju pertumbuhan PDB per kapita Cina selama tahun 1991-2010 berbanding lurus dengan tingkat investasi dalam bentuk modal fisik dan modal manusia.

Sebagai negara berkembang, Indonesia tergolong negara industri baru (new industrialized country). Transisi menuju negara industri baru disertai dengan perubahan output (PDB) yang merupakan salah satu indikator makroekonomi. Selain pertumbuhan ekonomi yang berkelanjutan, taraf hidup juga terus 
membaik. Sejak tahun 2000, perekonomian Indonesia berkembang ke arah yang benar, atau dua tahun setelah krisis ekonomi 1998, Indonesia mengalami pertumbuhan ekonomi yang moderat dan stabil.

Di Indonesia, penanaman modal asing langsung berperan penting dalam memenuhi kebutuhan penanaman modal dalam negeri. Penanaman modal asing langsung meningkatkan kapasitas produksi dan menjadi media transfer teknologi dari luar negeri ke dalam negeri. Dari sisi produksi, penanaman modal asing langsung dapat meningkatkan produktivitas perusahaan dalam negeri melalui transfer teknologi, dan adanya penanaman modal asing juga dapat meningkatkan daya saing dan keunggulan produk dalam negeri.

Jumlah Investasi Asing Langsung yang masuk ke Indonesia terus mengalami peningkatan dari satu dekade ke dekade berikutnya. Pada tahun 1990, besaran Investasi Asing Langsung adalah 1.433.669 ribu US\$ meningkat menjadi 6.257.129 ribu US\$ pada tahun 2000 dan 9.568.561 US\$ pada tahun 2012.

Perkembangan indikator Modal Manusia yang diproksi dengan rata-rata lama bersekolah (mean years of schooling of adult) selama periode penelitian juga terus meningkat dimana rata-rata lama bersekolah.

\section{Tinjauan Literatur (Literature Review)}

\section{a. Investasi Asing Langsung}

Salvatore (2017) menyebutkan bahwa Investasi Asing Langsung meliputi investasi ke dalam aset-aset secara nyata, seperti pembangunan pabrik-pabrik, pengadaan berbagai macam barang modal, pembelian tanah untuk kepentingan produksi, pembelanjaan berbagai peralatan investaris dan sebagainya. Manajemen aset ini biasanya untuk menjalankan fungsi manajemen, dan investor itu sendiri (pemilik aset) menjaga kendali atas dana yang diinvestasikan.

Penanaman modal asing langsung di Indonesia biasanya mengambil dua bentuk, yaitu (Anoraga, 2006):

\section{Investasi Portofolio}

Investasi Portofolio dilakukan melalui pasar modal dengan menggunakan instrumen portofoilo seperti saham dan obligasi. Dalam investasi ini, dana perusahaan yang digunakan untuk menerbitkan surat berharga (emiten) belum tentu menciptakan lapangan kerja baru.

\section{Investasi langsung}

Investasi langsung asing (FDI) memiliki lebih banyak keuntungan. Selain bersifat jangka panjang / jangka panjang, penanaman modal asing juga memfasilitasi transfer teknologi, alih keterampilan manajemen dan menciptakan lapangan kerja baru.

Dalam Undang-Undang Nomor 25 tentang Penanaman Modal Tahun 2007, undang-undang tersebut mengatur bahwa penanaman modal asing adalah kegiatan penanaman modal yang dilakukan di wilayah negara Republik Indonesia, yang dilakukan oleh penanam modal asing yang menggunakan modal asing yang seluruhnya atau bersama-sama dengan penanam modal dalam negeri. Yang dimaksud modal asing dalam undang-undang ini adalah:

1. Alat pembayaran luar negeri yang bukan merupakan bagian dari aset devisa Indonesia dapat digunakan untuk mendanai perusahaan Indonesia dengan persetujuan pemerintah.

2. Peralatan perusahaan yang dimasukkan ke dalam wilayah Indonesia dari luar, termasuk penemuan baru dan bahan milik orang asing, sepanjang alat tersebut tidak dibiayai dari kekayaan devisa Indonesia.

3.Menurut undang-undang, sebagian dari pendapatan perusahaan diperbolehkan untuk mentransfer keuntungan, yang masih digunakan untuk pembiayaan perusahaan di Indonesia.

\section{b. Modal Manusia}

Secara teori, menurut beberapa ekonom, misalnya (Becker, 2002), human capital diartikan sebagai pengetahuan, informasi, ide, keahlian, dan kesehatan individu. Pada saat yang sama (Acemoglu \& Autor, 2005) mendefinisikan modal manusia sebagai sesuatu yang berkaitan dengan karakteristik pekerja yang memberikan pengetahuan atau memiliki karakteristik bawaan atau diperoleh yang berkontribusi pada "produktivitas".

(Cohen \& Soto, 2007) menjelaskan tentang perkembangan metode kontribusi human capital, di antaranya pandangan bahwa kontribusi human capital dapat mengarah pada pertumbuhan yang berkelanjutan merupakan salah satu kritik yang dilontarkan oleh "New Growth". (Lucas, 1988) dan (Romer, 1990). 
Teori human capital juga cenderung menyamakan tingkat pengetahuan pekerja dengan tingkat sekolah formal mereka. Hal ini dapat mengindikasikan bahwa dengan melihat lamanya sekolah seseorang dapat mengestimasi economic individual return (yang berupa pendapatan) dari pembelajaran yang diperoleh seseorang. Bersekolah yang lebih lama sesuai jenjang pendidikannya akan menghasilkan produktivitas dan pertumbuhan ekonomi makro yang lebih tinggi.

Penelitian pertumbuhan ekonomi awal selalu mengacu pada penelitian yang dilakukan oleh Solow (1956) yang memberikan model dasar pertumbuhan ekonomi, dimana tabungan merupakan penggerak utama pertumbuhan ekonomi. Perkembangan analisis pertumbuhan ekonomi memberikan landasan bagi peran modal manusia sebagai bagian penting dalam mendorong pertumbuhan ekonomi (Mincer, 1984; Becker et al., 1990). Mankiw dkk. (1992) menggunakan model Augmented Solow Growth, di mana sumber daya manusia digunakan sebagai faktor produksi tambahan, dan model pertumbuhan endogen juga diadopsi. Para ahli melakukan beberapa studi lebih lanjut untuk menganalisis dampak modal manusia terhadap pertumbuhan ekonomi. (Lucas, 1988; Romer, 1990). Ini juga menghubungkan modal manusia dan adopsi teknologi sebagai faktor penting dalam mendorong pertumbuhan ekonomi.

\section{Metodologi Penelitian (Methodology)}

\section{a. Metode Analisa Data}

Untuk menguji pengaruh Investasi Asing Langsung dan Modal Manusia terhadap Pertumbuhan Ekonomi di Indonesia periode tahun 1990 - 2012 digunakan formula analisis regresi linear berganda (Multiple Regresion) di formulasikan sebagai berikut (Yusi dan Umiyati, 2020) :

Dimana :

$$
\mathbf{Y}=\mathbf{a}+\mathbf{b}_{1} \mathbf{X}_{1}+\mathbf{b}_{2} \mathbf{X}_{2}+\mathbf{e}
$$

$\mathrm{Y} \quad=$ Pertumbuhan Ekonomi

a $\quad=$ Konstanta

$\mathrm{b} 1, \mathrm{~b} 2=$ Koefisien regresi

$\mathrm{X}_{1} \quad=$ Investasi Asing Langsung

$\mathrm{X}_{2} \quad=$ Modal Manusia

$\mathrm{e} \quad=$ Error term tingkat kesalahan

\section{b. Operasional Variabel Penelitian}

Operasional variabel penelitian terdiri dari variabel terikat dan variabel bebas. Masing-masing variabel tersebut dijelaskan sebagai berikut.

- Y adalah pertumbuhan ekonomi diproksi dengan Produk Domestik Bruto

- $\quad X_{1}$ adalah investasi asing langsung

- $\quad \mathrm{X}_{2}$ adalah merupakan indikator dari Modal Manusia yang diproksi dengan rata-rata lama bersekolah (mean years of schooling of adult)

\section{Hasil dan Pembahasan (Results and Discussion)}

\section{a. Hasil Penelitian}

Untuk melihat pengaruh Investasi Modal Asing dan Modal Manusia terhadap pertumbuhan ekonomi di Indonesia dapat dilihat tabel berikut :

\section{Tabel 1}

Hasil Estimasi Fungsi Regresi

Dependent Variable: LOG(Y)

Method: Least Squares

Sample: 19902012

Included observations: 23

\begin{tabular}{crccc}
\hline \hline Variable & Coefficient & Std. Error & t-Statistic & Prob. \\
\hline \hline C & 22.75462 & 0.625806 & 36.36052 & 0.0000 \\
LOG(X1) & 0.088498 & 0.029132 & 3.037843 & 0.0065 \\
LOG(X2) & 0.874702 & 0.112321 & 7.787498 & 0.0000 \\
\hline \hline R-squared & 0.807091 & Mean dependent var & 26.25794 \\
Adjusted R-squared & 0.787800 & S.D. dependent var & 0.285584
\end{tabular}


S.E. of regression

Sum squared resid

Log likelihood

F-statistic

Prob(F-statistic)
0.131555

0.346133

15.62331

41.83794

0.000000
$-1.097679$

$-0.949571$

$-1.060431$

0.537314

Sumber : Hasil Regresi (2020)

Berdasarkan hasil regresi, hubungan antara investasi asing langsung dan modal manusia dengan pertumbuhan ekonomi dapat dituliskan sebagai berikut :

$$
\mathrm{Y}=22.75+0.08 \mathrm{X}_{1}+0.87 \mathrm{X}_{2}
$$

Hasil estimasi terhadap model menunjukkan bahwa variabel dependen pertumbuhan ekonomi (Y) dapat dijelaskan oleh variabel independen Investasi Asing Langsung $\left(\mathrm{X}_{1}\right)$ dan Modal Manusia $\left(\mathrm{X}_{2}\right)$ sebesar 80,71 persen sedangkan sisanya dijelaskan oleh variabel lainnya yang tidak digunakan dalam penelitian ini.

Secara rata-rata, setiap kenaikan 1 persen Investasi Asing Langsung akan meningkatkan pertumbuhan ekonomi sebesar 0,08 persen dan setiap kenaikan 1 persen indikator Modal Manusia yang diproksi dengan rata-rata lama bersekolah akan meningkatkan pertumbuhan ekonomi sebesar 0,87 persen.

Variabel Investasi Asing Langsung dan Modal Manusia mempunyai nilai probabilitas signifikan dan mempunyai nilai koefisien yang bertanda positif, mengindikasikan bahwa ke dua variabel tersebut mampu mendorong pertumbuhan ekonomi Indonesia

Investasi Asing Langsung merupakan salah satu faktor pendorong pertumbuhan ekonomi di suatu negara dan juga merupakan faktor yang berkontribusi terhadap kesenjangan antar negara (Ali et al, 2013). Penelitian yang pernah dilakukan oleh Athukorala dan Menon (1996) dan Aoki (1992) menyimpulkan bahwa investasi asing langsung sangat berkontribusi terhadap pembangunan di banyak negara berkembang. Dengan adanya Investasi asing langsung berpotensi menciptakan lapangan pekerjaan, meningkatkan produktivitas secara keseluruhan, meningkatkan daya saing dan kewirausahaan, dan akhirnya memberantas kemiskinan melalui pertumbuhan ekonomi dan pembangunan (UN, 2002).

Variabel indikator Modal Manusia yang dalam penelitian ini diproksi dengan rata-rata lama bersekolah (mean years of schooling of adult) berdasarkan hasil regresi menunjukkan bahwa sangat mempengaruhi pertumbuhan ekonomi. Peran Modal Manusia terhadap pertumbuhan ekonomi telah banyak dikaji oleh berbagai peneliti. Mankiw et al (1992) dengan menggunakan model augmented Solow menunjukkan bahwa negara yang memiliki higher levels of human capital akan mampu mendorong tingkat pertumbuhan ekonomi yang lebih tinggi dibandingkan dengan negara yang memiliki lower levels of human capital. Hasil penelitian ini selaras dengan penelitian yang pernah dilakukan oleh Bloom et al (2001) yang menemukan bukti bahwa human capital yang diproksi dengan mean years of schoolling berpengaruh secara signifikan terhadap pertumbuhan ekonomi dan Syahriani, et al (2015) yang juga menemukan bukti pengaruh Human Capital terhadap pertumbuhan ekonomi di Kawasan Asia Pasifik.

\section{Simpulan (Conclusion)}

1) Penelitian ini menguji peranan Investasi Asing Langsung dan Modal Manusia terhadap pertumbuhan ekonomi di Indonesia. Data yang digunakan adalah data time series periode 1990 sampai dengan 2012.

2) Hasil penelitian menunjukkan bahwa Investasi Asing Langsung dan Modal Manusia mempengaruhi pertumbuhan ekonomi di Indonesia. Dari ke dua variabel tersebut diketahui bahwa variabel Modal Manusia lebih mempengaruhi pertumbuhan ekonomi di Indonesia di bandingkan dengan variabel Investasi Asing Langsung.

\section{DAFTAR PUSTAKA (References)}

1) Acemoglu, D \& D. Autor, 2005. Lectures in Labor Economics. s.1.:MIT.

2) Ali, Hasnah, A.C. Er, A.R. Ahmad, N. Lyndon and Sanep Ahmad, 2013. An Analysis of the Impact of Foreign Investment on Regional Disparities : A case of Malaysia. Asian Social Science, 9(14), pp. 717.

3) Athukorala, Premachandra and Menon, Jayant, 1996. Foreign Investment and Industrialization in Malaysia : Exports, Employment and Spillover. Asian Economic Journal, 1(1), pp. 29-44. 
4) Becker, G.S, Murphy, K.M \& Tamura, R, 1990. Human Capital, Fertility, and Economic Growth. Journal of Political Economy, 98(5), pp. 512-537.

5) Bloom, D, Canning, D and Sevilla, J, 2001. Health, Human Capital and Economic Growth. $C M H$ Working Paper Series, Volume WG1:8.

6) Cohen, D \& Soto, M, 2007. Growth and Human Capital : Good Data, Good Results. Journal of Economic Growth, Volume 12, pp. 51-76.

7) Lucas, R., 1988. On the Mechanics of Economics Development. Journal of Monetary Economics, Volume 22, pp. 3-42.

8) Mankiw, N.G, Romer, D \& Well, D.N, 1992. A Contribution to the Empirics of Economic Growth. The Quarterly Journal of Economics, 107(2), pp. 407-437.

9) Mincer, J., 1984. Human Capital and Economic Growth. Economics of Education Review, 1(1), pp. 195-205.

10) Anoraga dan Pakarti, 2006. Pengantar Pasar Modal. Jakarta: PT. Rineka Cipta.

11) Romer, P., 1990. Human Capital and Growth : Theory and Evidence. Carnegie Rochester Conference Series on Public Policy, Volume 32, pp. 251-286.

12) Solow, R., 1956. A Contribution to the Theory of Economic Growth. Quartely Journal of Economics, pp. 65-94.

13) Yusi, M. Syahirman dan Umiyati Idris, 2020. Statistika untuk Ekonomi, Bisnis dan Sosial. Yogyakarta: Andi.

14) Syahriani, E, Muhammad, S, Sirojuzilam L and Syahnur, S, 2015. Natural Gas Trading and Economic Growth Convergence in Asia Pasific Region. International Journal of Contemporary Applied Sciences, 12(2), pp. 14-26.

15) Su, Yaqin and Liu, Zhiqiang, 2016. The Impact of Foreign Direct Investment and Human Capital on Economic Growth : Evidence from Chinese Cities. China Economic Review, 37(C), pp. 97-109. 